\title{
Research, Development and Application of High Performance Earthquake Resistant Precast System as Green Construction in Indonesia
}

\author{
Hari Nurjaman ${ }^{1, *}$, Binsar Hariandja ${ }^{2}$, Gambiro Suprapto ${ }^{3}$, Lutfi Faizal ${ }^{4}$ and Haerul Sitepu ${ }^{5}$ \\ ${ }^{1}$ Indonesian Association of Precast and Prestressed Engineer, 13440 Jakarta, Indonesia \\ ${ }^{2}$ Professor of Civil Engineering, Bandung Institute of Technology, School of Civil and Environmental \\ Engineering, 40132 Bandung, Indonesia \\ ${ }^{3}$ Wijaya Karya Beton, Ltd., Engineering Department, 17411 Jakarta, Indonesia \\ ${ }^{4}$ Ministry of Public Works and Housing, Puslitbang Perkim, 40393 Bandung, Indonesia \\ ${ }^{5}$ Ministry of Public Works and Housing, Ditjen Penyediaan Perumahan, 12110 Jakarta, Indonesia
}

\begin{abstract}
Sustainable construction is a topic that emerges in the world construction as a response to climate change issue. Building construction stage is a stage in sustainable development. Construction concept that confirm to the concept is referred to as green construction. Precast concrete construction is a construction system that meets green construction criteria, because applies the usage of material and construction method that optimize energy consumption and minimize environment impact during construction. This paper describe the qualitative and quantitative research in precast structures as green construction in Indonesia. Qualitative research was conducted on the assessment criteria of Green Building Council of Indonesia (2012-2014). The quantitative researches are in energy consumption and environmental influence of several construction systems which were conducted at low cost housing construction in Batam (2011-2012). Finally the research (2013-2014) and application (20152017) of high performance earthquake resistant precast concrete structure at low cost in Indonesia is described. The result of this research is expected to be a contribution to all construction stakeholders, in order to start to consider optimization of energy consumption in construction, and to become part of sustainable earth movement.
\end{abstract}

\section{Introduction}

Sustainable construction is an aspect developed worldwide as a response to climate change. Basic principle of such construction method is the use of energy in integrally optimal fashion starting from design, construction, operation, and demolition. Concrete precast system is a method of construction conforming to green construction, since the system applies efficient working method and material such that energy is used optimal. The paper presents qualitative and quantitative research on concrete precast system as green construction in Indonesia, followed by some applications and conclusions.

${ }^{*}$ Corresponding author: iappi ind $@$,yahoo.com 


\section{Qualitative research}

Qualitative research performed on research works by Green Building Council of Indonesia (GBCI) (2012-2014) to inspect how precast construction was elaborated in the determination of green construction category. Generally, there exist seven aspects in building assessment, should that building be designed with sustainable concept, as shown in Table 1 [9].

Table 1.Components of assessment of the building with the concept of sustainable development.

\begin{tabular}{|c|c|}
\hline Category & Precast concrete contribute to greenship points \\
\hline Appropriate Site Development & ASD 6-M icro climate (Heat island effect - Albedo) \\
\hline Energy Efficiency and Conservation & EEC P2 - OTTV calculation \\
\hline Water Conservation & \\
\hline Material Resources and Cycle & $\begin{array}{c}\text { MRC } 1-\text { Building and material reuse } \\
\text { MRC } 5-\text { M odular design/prefab material } \\
\text { MRC } 6-\text { Regional material }\end{array}$ \\
\hline Indoor Health and Comfort & IHC $3-$ Chemical pollutant \\
\hline Building Environment Management & BEM 2 - Pollution of Construcion Activity \\
\hline Innovation & \\
\hline
\end{tabular}

Building construction stage is a stage in sustainable development. Construction concept that conforms to this concept is referred to as green construction. Main principle in green construction is the use of $3 \mathrm{R}$ (reduce, reuse, recycle) concept in material use. Concrete precast system is a construction system that conforms to this concept. Reduce principle applies to the efficient use of materials and working method. The design of precast system may conserve the use of steel, which has most high emission dan generally available as imported material. The method of construction may conserve the use of formwork as depicted in Fig. 1a, conserve the use of propping as depicted in Fig. 1b, and also may avoid waste in the use of reinfocement and concrete as depicted in Fig. 1c.

The reuse principle mainly applied to the repetitive use of mold as compared to conventional system. Penolin triplex layers as depicted in Fig. 1d can be used 10@15 times compared to the use of only $2 @ 3$ times of conventional system. If fiber or steel is u sed, the mold may be used hundred of times. Recycle principle may be applied by using metal or fiber mold, and on green labeled grouting materials

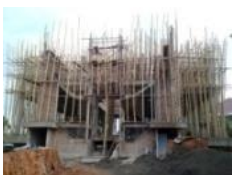

(a) conventional

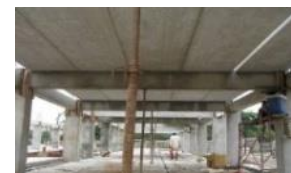

(b) propping system

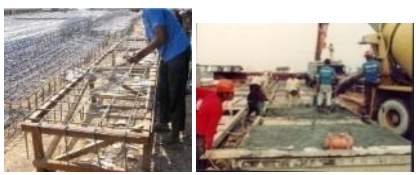

(c) zero wasted for steel and concrete

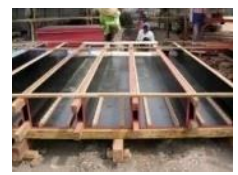

(d) molding system

Fig. 1.Conventional system and $3 R$ principle of precast system

\section{Quantitative research}

Quantitative research was performed on the use of energy and its environmental impact on several construction systems of low cost apartments in Batam (2011-2012) [9], and earthquake resistant high performance precast systems with low initial investation in Indonesia (2013-2014) [10-12]. 


\subsection{Calculation concept of construction energy and environmental impact}

Energy calculation reference of each item of construction work is based on Goedkoop and Oele [14]. Equalization process for comparis on of each item is done by LCA (life cycle analysis) method through Simapro 5.0 software to analyze environmental aspect related to a product and its life cycle, starting from retrieval, production, use, maintenance until demolition and bringing the material back to nature. The software calculates input data such as raw material quantities, and produces output to guide safer return to the nature.

\subsubsection{Construction system}

Rental apartment was made of concrete conctruction, which made through three construction methods, i.e., conventional, partial precast and full precast. Conventional concrete system uses conventional process in view of structural as well as architectural aspects. The construction uses cast in-situ process using timber molding and scaffolding. Architectural wall components are made of bricks or concrete blocks.

Partial precast concrete system uses precast components and architectural components are made of conventional bricks or concrete blocks as shown in Fig. 2a. Full precast concrete system uses precast for both structural and architectural components as shown in Fig. 2b.

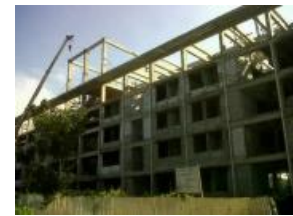

(a) partial precast system

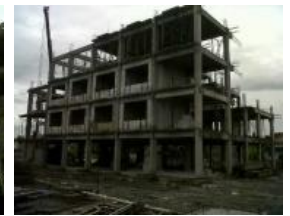

Fig. 2.Variate of precast system

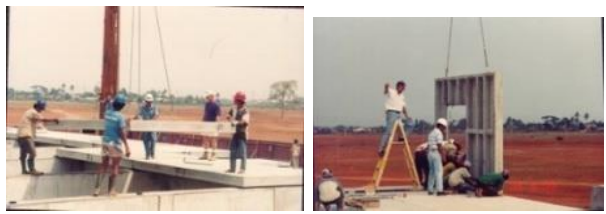

(b) full precast system

\subsubsection{Calculation of construction energy and environmental impact}

Construction of rental low cost apartment requires natural resources as construction raw material. The use of natural resources may cost natural damage. Main construction materials with corresponding demands on each construction type may be seen in Table 2 .

The use of reinforcement bar in precast system has been significantly decreases from 180 tons in conventional concrete to 77 tons in partial precast. The significant saving on reinforcement is achieved due to the use of prestrssed grid in slab component. Similar condition also occurs on the use of timber, as scaffolding or as molding to $603 \mathrm{~m}^{3}$. The timber no longer needed for partial as well as full precast concrete. Beside efficiency in the use of construction materials, additional advantage from using partial or full precast concrete is the cost reduction due to shorter construction time, from 8 months to 5-6 months. On the other hand, the total use of labors in precast construction is less then needed for conventional work. However, precast concrete work needs more skilled labors. This is in accordance with that stated by Gibb [1].

The result of the analys is of conventional system of single score in Fig. 3a. shows that steel bar is an element that gives the most impact $(8.19 \mathrm{kPt})$, followed by cement $(4.55 \mathrm{kPt})$. The result single scoring on partial concrete precast system application in Fig. 3b. shows that cement is the element that provides greatest impact $(4.7 \mathrm{kPt})$, folowed by steel reinforcement $(3.59 \mathrm{kPt})$. 
Table 2.Building material needs

\begin{tabular}{|r|l|r|r|r|}
\hline No & \multicolumn{1}{|c|}{ Main component } & Conventional & Partially Precast & \multicolumn{1}{c|}{ Full Precast } \\
\hline 1 & Cement & $488 \mathrm{ton}$ & 499 ton & 617 ton \\
\hline 2 & Fine aggregate & $3,483 \mathrm{~m} 3$ & $3,354 \mathrm{~m} 3$ & $687 \mathrm{~m} 3$ \\
\hline 3 & Coarse aggregatre & $339 \mathrm{~m} 3$ & $398 \mathrm{~m} 3$ & $642 \mathrm{~m} 3$ \\
\hline 4 & Reinforcement bar & 180 ton & 77 ton & 122 ton \\
\hline 5 & Mold & wood $41 \mathrm{~m} 3$ & steel 7.9 ton & steel 9.2 ton \\
\hline 6 & Scaffolding & $413,216 \mathrm{mos}$ & $413,216 \mathrm{mos}$ & - \\
\hline 7 & Brick & $20 \mathrm{man}$ & $30 \mathrm{man}$ & $40 \mathrm{man}$ \\
\hline 8 & Skilled labour & $80 \mathrm{man}$ & $45 \mathrm{man}$ & $15 \mathrm{man}$ \\
\hline 9 & Unskilled labour & 13.657 & 11.500 & 11.434 \\
\hline 10 & Cost (Rp x 1.000 million) & $4 \mathrm{lt} / 4,600 \mathrm{~m} 2$ & $4 \mathrm{lt} / 4,600 \mathrm{~m} 2$ & $4 \mathrm{lt} / 4,600 \mathrm{~m} 2$ \\
\hline 11 & No. of stories /area & 8 & 6 & 5 \\
\hline 12 & Construction time (month) & & steel 7.8 ton \\
\hline
\end{tabular}

*) Precast technology used is from one of the national precaster

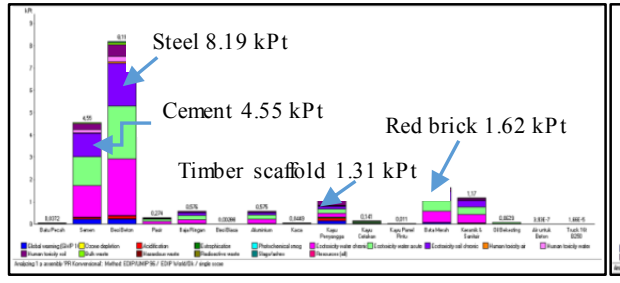

(a) conventional system

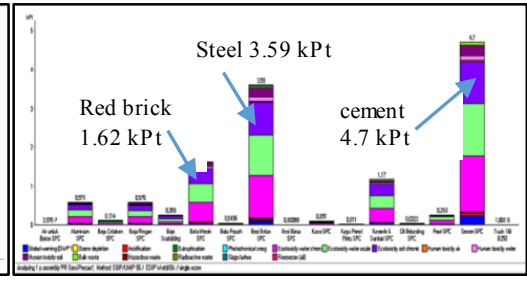

(b) partial precast system

Fig. 3. LCA single score results

Aspects that differentiate the materials used in the full precast concrete system to partially precast concrete system is a reduction in the use of raw materials for the manufacture of wall plaster, cement, sand, and red brick. The reduction of raw materials of wall was substituted entirely by the use of precast concrete. The result of the analys is of full precast system of single score in Fig. 4a. shows that steel bar is a contributor to the process that could provide the greatest impact $(6.81 \mathrm{kPt})$, followed by cement $(3.82 \mathrm{kPt})$.

The result of a single aggregate score shownin Fig. 4b. Overall environmental impact due to the life cycle of the contributors to the conventional use of concrete is $18.6 \mathrm{kPt}$. This could be reduced to only $13.8 \mathrm{kPt}$ with full precast concrete and toonly $13.0 \mathrm{kPt}$ with partially precast concrete. While the difference in ability between full precast concrete to partially precast concrete is $6 \%(0.8 \mathrm{kPt})$ in reducing the environmental impact.

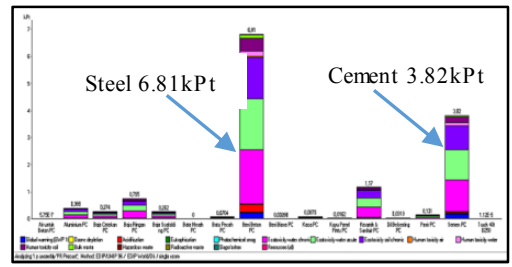

(a) full precast system

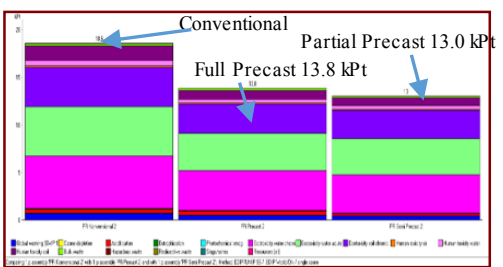

(b) comparison on each altern

Fig. 4. LCA single score

The main building materials that have the greatest environmental impact are steel bars, cement, aluminium, bricks, ceramics and sanitary, as presented in Table 3. Base on weighting, almost all elements of potential environmental impact of the three dominant (impact catagories), namely: (1) chronic aquatic environmental toxicity (2) acute toxicities of aquatic environments, (3) chronic toxicities of environmental soil. Chronical aquatic environmental poisonous content is caused by materials that contaminate aquatic in long time period. If that contamination is not taken care seriously and correctly, the impact would propagate to accute aquatic poisonous environmental contamination. This is hazardous to human being and living organism that utilize the aquatic. 
Table 3.Comparison of environmental impact

\begin{tabular}{|c|c|c|c|c|}
\hline \multirow{2}{*}{$\begin{array}{c}\text { Construction alternative } \\
\text { dan } \\
\text { pollutant potential of main } \\
\text { building material }\end{array}$} & \multicolumn{3}{|c|}{ Environmental impact catagory $(\mathrm{Pt})$} & \multirow[b]{2}{*}{$\begin{array}{c}\text { Energy } \\
(\text { kWh) }\end{array}$} \\
\hline & $\begin{array}{c}\text { Chronic toxic } \\
\text { waters }\end{array}$ & $\begin{array}{l}\text { Acute toxic } \\
\text { waters }\end{array}$ & $\begin{array}{c}\text { Chronic toxic } \\
\text { soils }\end{array}$ & \\
\hline $\begin{array}{l}\text { Conventional: } \\
\text {-steel bar } \\
\text {-cement } \\
\text {-aluminum }\end{array}$ & $\begin{array}{l}5.18 \times 10^{8} \\
2.85 \times 10^{8}\end{array}$ & $\begin{array}{l}4.95 \times 10^{7} \\
3.68 \times 10^{6}\end{array}$ & $\begin{array}{l}2.53 \times 10^{7} \\
1.39 \times 10^{7}\end{array}$ & $1,253,774.7$ \\
\hline $\begin{array}{l}\text { Partially precast: } \\
\text {-cement } \\
\text {-steel bar } \\
\text {-red brick }\end{array}$ & $\begin{array}{l}2.94 \times 10^{8} \\
2.27 \times 10^{8}\end{array}$ & $\begin{array}{c}2.82 \times 10^{7} \\
- \\
9.97 \times 10^{6}\end{array}$ & $\begin{array}{l}1.43 \times 10^{7} \\
1.11 \times 10^{7}\end{array}$ & $806,981.9$ \\
\hline $\begin{array}{l}\text { Full precast: } \\
\text {-steel bar } \\
\text {-cement } \\
\text {-ceramic \& sanitary }\end{array}$ & $\begin{array}{l}4.11 \times 10^{8} \\
2.39 \times 10^{8}\end{array}$ & $\begin{array}{l}3.92 \times 10^{7} \\
2.29 \times 10^{7}\end{array}$ & $\begin{array}{l}1.97 \times 10^{7} \\
3.65 \times 10^{6}\end{array}$ & $1,008,199.9$ \\
\hline
\end{tabular}

\subsection{The research of high performance earthquake resistant precast structure}

High performance earthquake resistant precast structure is a revolutionary alternative technological solution capable of achieving high-performance (low damage) at low cost. This concept was developed in US-Japan joint research PRESSS Program (1994-2002) and New Zealand in the late 1990s [16], as a response to public demands for the performance of classical ductile design concept that did not comply with their expectation in Loma Prieta (1989) and Northridge (1994) earthquake. The well-known ductile design concept using collapse prevention performance criteria can indeed avoid casualties in a strong intensity earthquake, but the associated structural damage can result in significant business interruption. Furthermore, the post-earthquake repairs can be challenging and costly.

\subsubsection{The concept of high performance earthquake resistant precast structure}

There are two main components involved within the system,i.e., unbonded posttensioning that provide re-centering effect, and mild reinforced concrete that provide energy dissipation (dissipater). Unbonded post-tensioning tendon may be applied in beamcolumn connection, and across vertical connection between precast wall, including walls and foundation [17] as shown in Fig. 5a. Unbonded post-tensioning, while kept elastic, is engineered to prevent residual deformations. Dissipater [17], on the other hand, are used to provide hysteresis damping as shown in Fig. 5b. Dissipaters can be designed as replaceable fuses in the structural system. The experience in Indonesia is that the use of these emerging technologies can be achieved without compromising the architecture of the building.

The difference in seismic response between high performance concept and the classical ductile behaviour may be observed from the test results of beam column joint. Fig. 6a. shows the hysteresis loops and joint damage pattern of classical ductile design that meet the requirements of special moment resisting frame (SMRF) [10]. Hysteresis is described by reasonably "fat" loops that occur in all four quadrants. Inelastic response results from development of plastic hinges, which exhibits structural damage and requires costly repairs. Moreover, such ductile system may experience residual deformations.

In re-centering system, the hysteretic response is essentially described by loops that appear diagonally in two opposite quadrants, as depicted in Fig. 6b. [17]. The beam-column joint in this Fig. exhibits re-centering effect due to the presence of an elastic unbonded post-tension tendon. This concept is also referred to as hybrid concept. The ratio of recentering and ductile behaviour will produce a spectrum hysteresis hybrid concept known as "flag shape". ACI 550.3-13 recommends prestressing force to be at least $50 \%$ of the load in order to conduct a re-centering remaining effective [4]. 


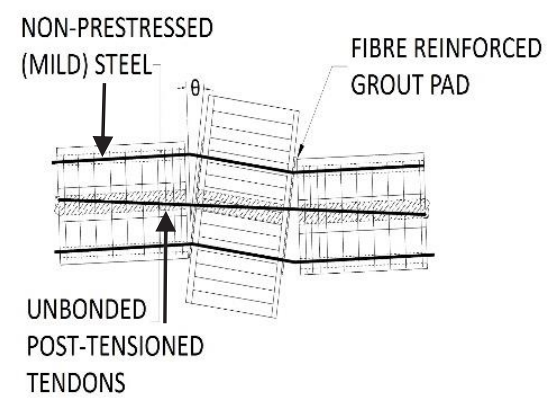

(a) Unbonded Post-tensioning

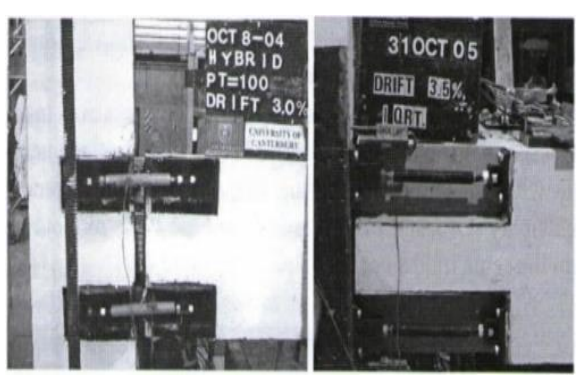

(b) Dissipater for hysteresis damping

Fig. 5.Two main component of high performance earthquake resistant precast structure [17]
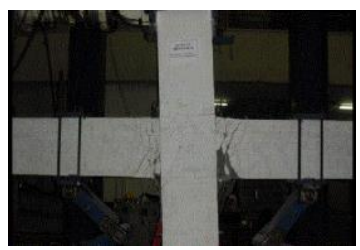

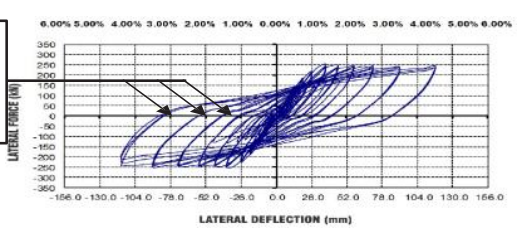

LATERRL DEFLECTION (mm)

(a) Classical ductile behaviour

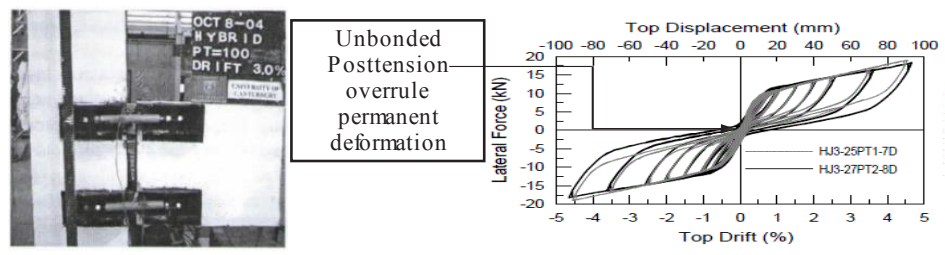

(b) High performance precast

Fig. 6.The difference in seismic response

\subsubsection{The development in Indonesia}

The development is based on technology and local materials that already exist. The concept of unbonded post tension is relatively well known, so that the material, equipment and construction methods is not difficult to be used as shown in Fig. 7a. The common configuration of a dissipater device consist of the connection of a steel bar using a smaller confined within a metal tube sheet [17]. A local dissipater device was developed successfully in 2014, based on Indonesian method of connecting steel bars, with spiral reinforcement made from plain bars, as shown in Fig. 8b. This spiralis equivalent to metal sheet tube

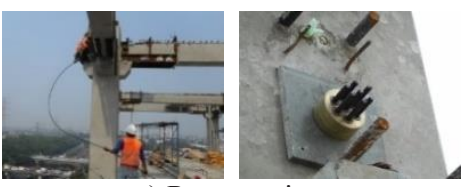

a) Post tension

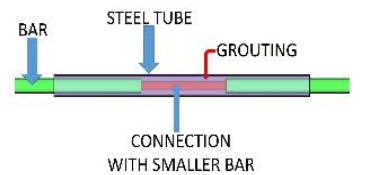

(b) Dissipater development

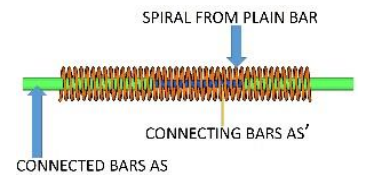

Fig. 7.High performance earthquake resistant precast system in Indonesia

Dissipater can be mounted externally or internally, as shown in Fig. 8. The advantages of external dissipater is that it can be replaced if damaged, but consequently disturbing the outlook of the system. The development achieved in Indonesia is slipping this tool at the 
top and bottom of the beam, so it does not disturb the outlook, and still easily replaced if damage.

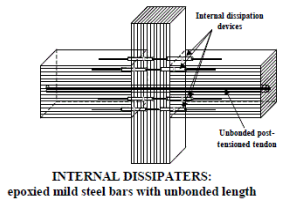

(a) Internal

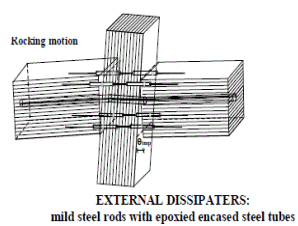

(b) External

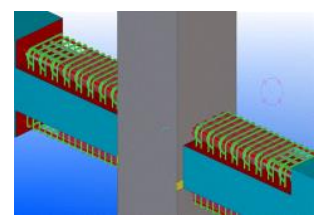

(c) Indonesian development

Fig. 8. Dissipater location

\subsubsection{Laboratory testing}

Testing of dissipater development is carried out following ASTM E8 tensile testing procedures [7]. ACI 550.3-13 states that the material must meet ASTM A706 Grade 60 [6]. The ratio of tensile strength to yield strength $\mathrm{f}_{\mathrm{s}} / \mathrm{f}_{\mathrm{y}}$ is not less than 1.25 , in accordance with Article 21.1.5.2 b ACI 318-08 [3]. It directs that the reinforcement ratio between connected bar to connection bar $\left(\mathrm{A}_{\mathrm{s}} / \mathrm{A}_{\mathrm{s}}\right.$ ') should be between $1-1.25$, so that yield occurs at connection bar, and the strain hardening phase will not overwhelm yield stress of connected bars. The dissipater test results [10] may physically be seen in Fig. 9.

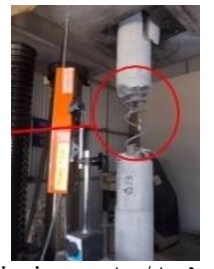

(a) DissipaterAs/As'=1.44

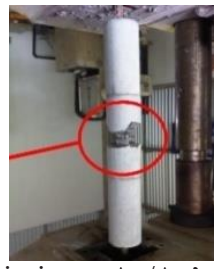

(b)DissipaterAs/As' $=1.14$

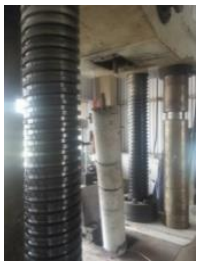

(c) Strong connection As'/As $=1.06$

Fig. 9. Dissipater test result

The beam column joint testing was done after some preliminary testing phase. Reinforcement of hybrid beam made according to preliminary test sample with a moment capacity ratio of dissipater bar to the probable moment capacity $\left(\mathrm{M}_{\mathrm{s}} / \mathrm{M}_{\mathrm{pr}}\right)$ approaching 0.5 , in according with recommendation or article 7.4.2 in ACI 550.3-13 [4]. Connected to connecting bar ratio was $\mathrm{A}_{\mathrm{s}} / \mathrm{A}_{\mathrm{s}}$ '= 1.14. Joint and column are designed in accordance with article 21.1.3, Article 21.6, and article 21.7 of ACI 318-08 [3]. Loading schemeand acceptance test criteria are based on ACI 374-05[2] as shown in Fig. 10. In drift up to $\Delta=$ $3.5 \%$, the specimen must meet three main criteria: strength, energy dissipation and stiffness in order to be categorized as Special Moment Resisting frame (SMRF). Analysis of testing result [12] showed that the beam-column joint meets the criteria of ACI 374-05 [2] as shown in Fig. 11.

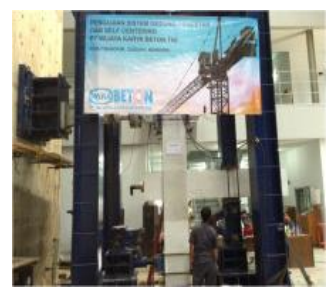

(a) Exterior joint

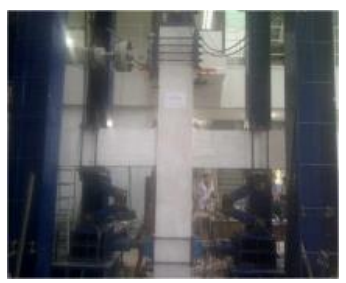

(b) Interior joint

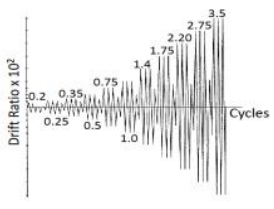

(c) Loading schemes

Fig. 10. Beam column joint test and loading scheme of ACI 374-05 [2] 

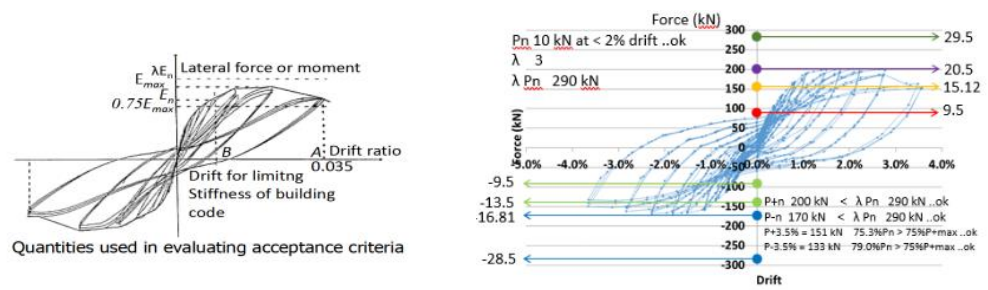

(a) Strength criteria
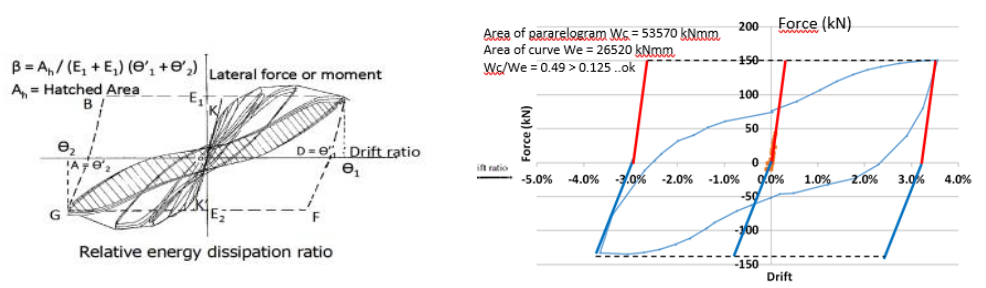

(b) Energy dissipation criteria
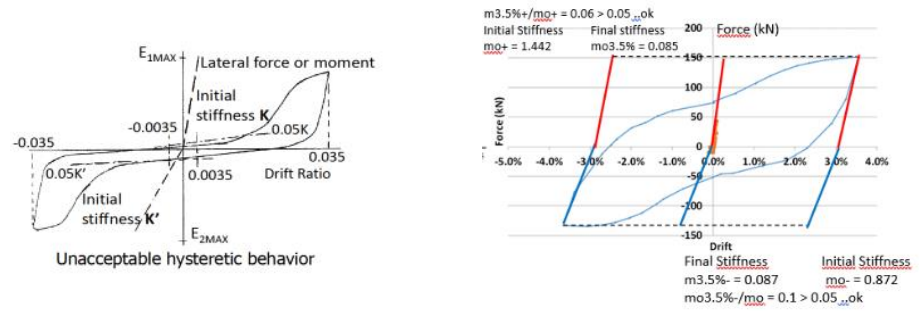

(c) Stiffness criteria

Fig. 11. Beam column join test criteria check by ACI 374-05 [2]

What is more interesting is the failure mechanisms of the test specimens and the performance level at each stage of the test, as shown in Fig. 12. Yield on the connecting bar started at $\Delta=1 \%$, and began to cause a gap at $\Delta=1.75 \%$. This gap opened and closed during cyclic loading, which demonstrates the effectiveness of "re-centering" feature caused by unbonded post tensioning system, as shown in Fig. 13b and 13c. The damage did not occur in other parts significantly until $\Delta=2.2 \%$, as shown in Fig. 13d. $\Delta_{\mathrm{a}}$ (allowable story drift) on earthquake design ( $\mathrm{S}_{\mathrm{DS}}$ ) as required in Table 12.2-1 ASCE/SEI 7-10 [5] is 2\% for risk category I or II. So it demonstrates a proven high performance on the structural systems, which the building would return to the original position, with the damaged concentrated in the dissipater components. The retrofitting can be done by replacing dissipater components. The hysteresis loop of hybrid system can be seen in Fig. 13g. This behaviour close to flag shape pattern in proportion of 50:50.

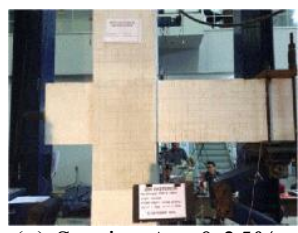

(a) Service $\Delta=0.35 \%$

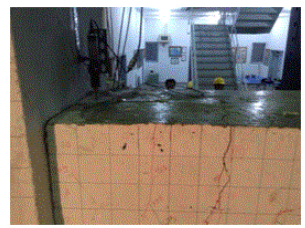

(b) gap in $\Delta=1.75 \%$

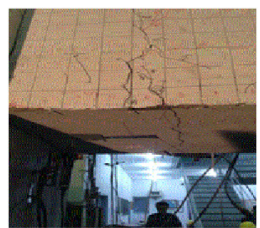

(c) gap in $\Delta=1.75 \%$

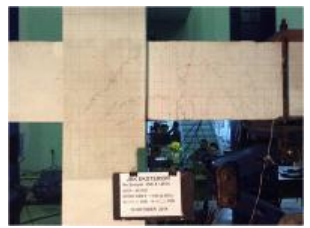

(d) $\Delta=2.2 \%$ equal $\mathrm{S}_{D S}$ and $\Delta_{\mathrm{a}}$ 


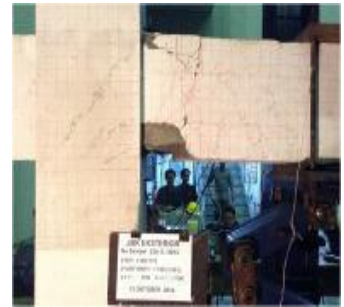

(e) $\Delta=3.5 \%$ equal $\mathrm{MCE}_{\mathrm{R}}$

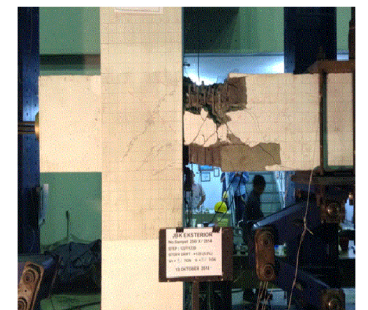

(f) $\Delta=5 \%$ equal near collapse

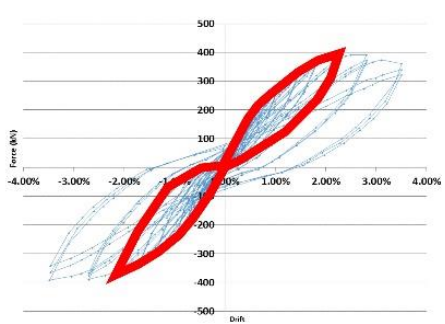

(g) Flag shape $50: 50$ at $\Delta=2.2 \%$

Fig. 12. Failure mechanism and specimen

\section{Application}

The system was applied to a twelve-storey office building in Jakarta (2014); some multi storey low cost housing in Jakarta, Banten and West Java(2015), Riau Island, Riau, North Sumatera, South Sumatera, and West Java (2016); low cost landed house (2015), shop house (2016), and hospital in Jakarta (2017), as shown in Fig. 13.High performance earthquake resistant precast system used in the columns, beams, and hollow core slab or half slab. The application proves resistant and can increase good quality construction with an easy, fast and economical.

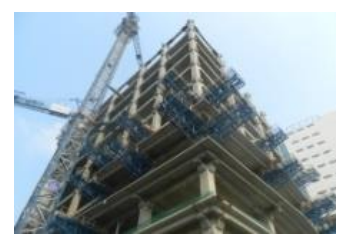

(a) 12 story office

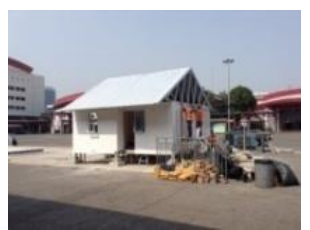

(b) Low cost housing

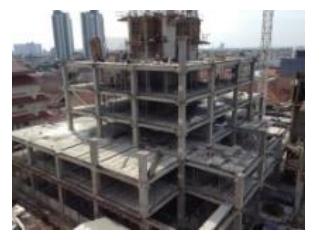

(c) Hospital

Fig. 13. Application

\section{Conclusion}

Sustainable construction is a topic that emerges in the world construction as a respond to climate change issue. Precast concrete is a construction system that meets green construction criteria, because the usage of material and construction method that optimize energy consumption and minimize environmental impact during construction are applied.

Precast building in Indonesia started to be applied commonly in government mass rental low-cost housing program (1995). Qualitative research was conducted on the assessment criteria of Green Building Council of Indonesia (2012-2014). The precast concrete building systems is one that meet this rule, that be elaborated in construction material. The quantitative researches were in energy consumption and environmental influence of several construction in Batam (2011-2012), which showed precast system is have less energy consumed and more environmental friendly than conventional system. Finally the research of high performance earthquake resistant precast concrete structure at low cost (2013-2014) had found specific system configuration based on local available material and technology. The system can guaranteed that the building is still functional in its life time even after influenced by major earthquake, and so can save energy consumption in repairment. Based on the successfully application, Indonesian government had set the target application of precast concrete about 30\% of construction industry until 2019.

The result of this research is expected to be a contribution to all construction stakeholder, in order to start to consider optimization of energy consumption and environmental impact in construction and to become part of sustainable earth movement. 
This research is funded by Pressstekindo Consultant Ltd, and Wijaya Karya Beton Ltd. The writers extend their appreciation to the Indonesian Association of Precast and Prestressed Engineers and to Ministry of Public Work and Housing for providing testing facilities.

\section{References}

1. A.G.F. Gibb, Off-site Fabrication (John Wiley and Sons, New York,1999)

2. American Concrete Institute, ACI 374-05 Acceptance Criteria for Moment Frames Based on Structural Testing and Commentary, 8-9 (2014)

3. American Concrete Institute, ACI 318-08 Building Code Requirement for Structural Concrete, 323-324,347-349 (2008)

4. American Concrete Institute, ACI 550.3-13 Design Specification for Unbonded PostTensioned Precast Concrete Special Moment Frame Satisfying ACI 374.1 and Commentary, 11,19,20 (2013)

5. American Society of Civil Engineers, ASCE/SEI 7-10 Moment Design Loads for Buildings and Other Structures, 374,66,97 (2010)

6. American Standard of Testing Material, ASTM A706/A706M-14 Standard Specification for Deformed and Plain Low-Alloy Steel Bars for Concrete Reinforcement, (2014)

7. American Standard of Testing Material, ASTM D : E8-09 Standard Test Methods for Tensioning Testing of Metallic Materials, (2009)

8. Badan Standar Nasional Indonesia, SNI 03-1726-2002 Standar Perencanaan Ketahanan Gempa untuk Struktur Gedung, 21,31 (2002)

9. H.N. Nurjaman, H. Sitepu, H.R. Sidjabat, Precast Concrete Construction : A Green Construction : Comparison of Construction Energy and Environmental Influence in Low Cost Housing Construction in Batam ( $1^{\text {st }}$ International Conference of Sustainable Civil Engineering Structure and Construction Material, Yogyakarta, 2012)

10. H.N. Nurjaman, L. Faisal, H.R. Sidjabat, B. Hariandja, R. Rivky, Y. Put, Elsevier Procedia Eng. J. 95, 82-86 (2014)

11. H.N. Nurjaman, L. Faisal, H.R. Sidjabat, G. Soeprapto, B. Hariandja, R. Rivky, Y. Put, Research Development and Application of Precast Systems for Building, with Connection using Unbonded Post-Tension and Local Dissipater Device $\left(6^{\text {th }}\right.$ International Conference of Asian Concrete Federation, Seoul, 2014)

12. H.N. Nurjaman, L. Faisal, G. Soeprapto, R. Rivky, Y. Put, B. Hariandja, J.I. Restrepo, H.R. Sidjabat, Research, Design and Application of High Performance Earthquake Resistant Precast Structure in Indonesia (16 ${ }^{\text {th }}$ World Conference of Earthquake Engineering, Santiago, 2017)

13. M.J. Scoettler, A. Belleri, D. Zhang, J.I. Restrepo, R.B. Fleischman, PCI. J. 54(1), 100 (2009)

14. M. Goedkoop, M. Oele, Database Manual General Introduction (Product Ecology Consultant, USA, 2001)

15. R.B. Fleischman, J.I. Restrepo, S. Pampanin, J.R. Maffei, K. Seeber, Earthquake Spectra 30 (1), 277-306 (2014)

16. S. Pampanin, PRESSS Design Handbook (New Zealand Concrete Society, 2010)

17. S.Pampanin, Reality-check and Renewed challenges in Earthquake Engineering: Implementation low-damaged System - from theory to practise $\left(15^{\text {th }}\right.$ World Conference of Earthquake Engineering, Lisboa, 2012) 